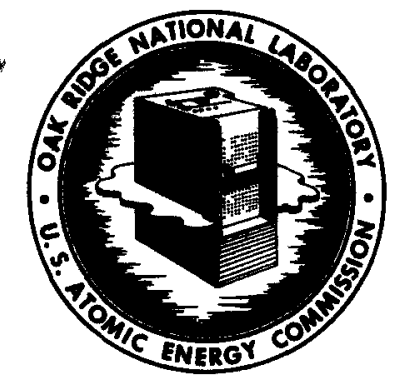

OAK RIDGE NATIONAL LABORATORY

operated by

UNION CARBIDE CORPORATION

for the

U.S. ATOMIC ENERGY COMMISSION

ORNL - TM- 1506

COPY NO. -

RELEASED FOR ANMOUNCEMENT

42

DATE - April 27, 1966

2. vUGLEAR SCIENCE abStracts

CALCULATION OF FISSION PRODUCT RADIOACTIVITY IN OFF-GASES

FROM A BURN-LEACH PROCESS FOR GRAPHITE-BASE FUELS

H. O. Witte ${ }^{a}$

ABSTRACT

CFSII PRICES

H.C. $\$ 1.0$; MW

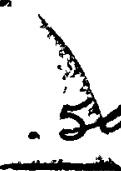

Equilibrium concentrations of fission product oxides in oxygen were calculated from thermochemical data. The calculations showed that, at high temperatures, an appreciable amount of fission product oxides can be expected in the off-gas from a burn-leach process for HTGR fuel. Cooling the off-gas to room temperature should condense practically all the volatile oxides since the equilibrium constants are highly temperature dependent. If the condensed axides can be removed from the off-gas by efficient filtration or scrubbing, the remaining radioactivity in the gas would be due predominantly to ${ }^{85} \mathrm{Kr}$. Stack-dilution calculations showed that, even under adverse conditions, the off-gas can probably be released by a 100-m stack without further dilution.

${ }^{{ }^{a}}$ Guest scientist from KFA, Juelich, Germany.

MOTICE This document contains informotion of a preliminary noture and was prepored primarily for internal use of the Oak Ridge National Laboratory. It is subject to revision or correction and therefore does not represent a final report. 
This report was prepared as an account of Government sponsored work. Neither the United States, nor the Commlssion, nor ony person acting on behalf of the Commission:

A. Mokes ony worranty or representation, expressed or implied, with respect to the accuracy, completeness, or usefulness of the information contained in this report, or that the use of any information, apporatus, method, or process disclosed in this report may not infringe privately owned rights; or

B. Assumes any liabilities with respect to the use of, or for damages resulting from the use of any information, apparafus, method, or process disclosed in this report.

As used in the above, "person acting on behalf of the Commission" includes any employee or controctor of the Commission, or employee of sueh contractor, to the extent that such employee or contractor of the Commission, or employes of such contractor propares, disseminates, or provides access to, any information pursuant to his employment of contract with the Commission, or his employmont with such contractor. 


\section{DISCLAIMER}

This report was prepared as an account of work sponsored by an agency of the United States Government. Neither the United States Government nor any agency Thereof, nor any of their employees, makes any warranty, express or implied, or assumes any legal liability or responsibility for the accuracy, completeness, or usefulness of any information, apparatus, product, or process disclosed, or represents that its use would not infringe privately owned rights. Reference herein to any specific commercial product, process, or service by trade name, trademark, manufacturer, or otherwise does not necessarily constitute or imply its endorsement, recommendation, or favoring by the United States Government or any agency thereof. The views and opinions of authors expressed herein do not necessarily state or reflect those of the United States Government or any agency thereof. 


\section{DISCLAIMER}

Portions of this document may be illegible in electronic image products. Images are produced from the best available original document. 
CONTENTS

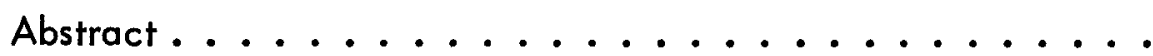

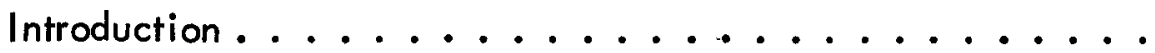

Consideration of Gas Phase Equilibria. . . . . . . . . .

Theoretical Background . . . . . . . . . . . .

Fission Product Volatilities . . . . . . . . . . .

Fission Product Yield ................

Off-Gas Activity . . . . . . . . . . . .

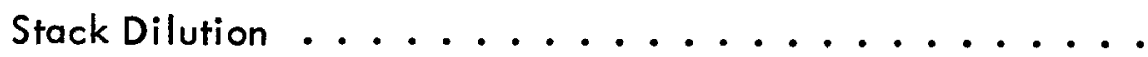

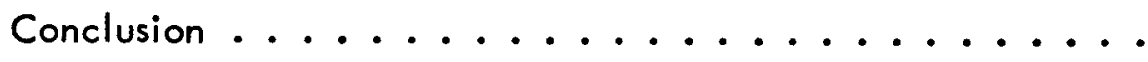

Acknowledgment ...................

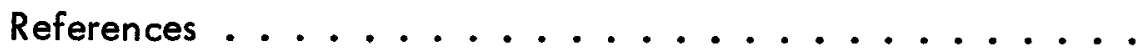

\section{LEGAL NOTICE}

Was account of Government sponsored work. Nellior: This report was prepared as an accoun of States, nor the Commission, nor any person acting expressed or implied, with respect that the use A. Makes any warranty or repres the information contained in this report may not infringe racy, completeness, or usefulness of the in process disclosed in this report of any information, appara privately owned rights; or

B. Assumes any labilities wh method, or process disclosed in this report includes any emof any information, apparatus, macting on behalf of the Comnisstor, to the extent that As used in the above, "pemmission, or employee of such en anch contractor prepares, ployee or contractor of the Com the Commission, or employee of gis employment or contrac such employee or contractor of the any information purguant such eminates, or provides access to, any with such contractor. diesemina Commisston, or his employment with such co 


\title{
CALCULATION OF FISSION PRODUCT RADIOACTIVITY IN OFF-GASES FROM A BURN-LEACH PROCESS FOR GRAPHITE-BASE FUELS
}

\author{
H. O. Witte
}

\section{INTRODUCTION}

In the burn-leach process, crushed graphite fuel elements containing pyrolytic carbon-coated carbide or oxide particles will be burned in a fluidized bed of alumina at about $750^{\circ} \mathrm{C}$. The behavior of the fission products during actual fluidized-bed combustion has not been studied, but some data were obtained in laboratoryscale tube-furnace experiments. ${ }^{1}$ Prototype Peach Bottom fuel irradiated to about 10,000 Mwd/metric ton (Th $+U$ ) was burned with a large excess of oxygen. Up to $35 \%$ of the cesium and $96 \%$ of the ruthenium were volatilized from the high-temperature zone during 6-hr combustions at $800^{\circ} \mathrm{C}$. Practically all the fission products condensed and were trapped in the cool end of the reaction tube, and nearly all remaining activity was removed by filtering the off-gas through a $40-\mu$-porosity sintered-metal filter. The overall decontamination factor was greater than $10^{4}$ in all experiments.

The purpose of this memo is to predict from thermochemical data the qualitative behavior of fission products during combustion. The results of these calculations will serve as a guide in planning fluidized-bed combustion experiments with irradiated fuel and in interpreting the results.

\section{CONSIDERATION OF GAS PHASE EQUILIBRIA}

Combustion in a fluidized-bed burner is achieved by using excess oxygen. Experimental data' show a typical steady-state off-gas composition of $90 \% \mathrm{CO}_{2}$ ' $5 \% \mathrm{CO}$, and $5 \% \mathrm{O}_{2}$, analyzed at about $25^{\circ} \mathrm{C}$ and 1 atm pressure. According to the equilibrium

$$
\mathrm{CO}+1 / 2 \mathrm{O}_{2}=\mathrm{CO}_{2}
$$


the $\mathrm{CO}_{2} / \mathrm{CO}$ ratio found in the burning experiments should have had equilibrium oxygen pressures of about $10^{-87}$ atm at $300^{\circ} \mathrm{K}$ and $10^{-18}$ atm at $1000^{\circ} \mathrm{K}$. On the other hand, with an actual oxygen pressure of about $0.05 \mathrm{~atm}$, the $\mathrm{CO}$ pressure should have been very low. In actual burning, we have relatively high pressures of both $\mathrm{O}_{2}$ and $\mathrm{CO}$; so, from the standpoint of thermochemical equilibrium, one cannot predict whether reduction by $\mathrm{CO}$ or oxidation by $\mathrm{O}_{2}$ will be the predominating reaction.

The formation of volatile fission product oxides in general increases with increasing oxygen pressure. For example, under the actual oxygen pressure ( $0.05 \mathrm{~atm})$, the stable ruthenium compound in the condensed phase is $\mathrm{RuO}_{2}$, which oxidizes to volatile $\mathrm{RuO}_{4}$. Under the actual $\mathrm{CO}$ pressure, the $\mathrm{RuO}_{2}$ should be reduced to elemental Ru, but this was not noted in the previously mentioned experiments. As to cesium, the stable condensed compound under the actual oxygen pressure is $\mathrm{Cs}_{2} \mathrm{O}$ at $1000^{\circ} \mathrm{K}$ and $\mathrm{CsO}_{2}$ at $500^{\circ} \mathrm{K}$. Under reducing conditions, the condensed phase is $\mathrm{Cs} \mathrm{O}$, which sublimes. In this case, cesium volatilization should be independent of the oxygen pressure and, because of the fairly high vapor pressure of gaseous $\mathrm{CsO}$ above condensed $\mathrm{CsO}$, should be markedly higher than the ruthenium volatilization. In the actual burning experiments, ruthenium volatilization was greater, and cesium volatilization was strongly dependent on the oxygen pressure. This indicates the predominating influence of the oxygen pressure on fission product volatilization. Hence, in the following calculations of fission product volatilization it was assumed that all reactions were predictable by the actual oxygen pressure. It was further assumed that the condensed phases of the fission products consisted of the oxides which are stable under the actual oxygen pressure and that each condensed phase was a pure phase with a chemical activity of unity. 


\section{THEORETICAL BACK GROUND}

Fission product volatilization is expressed by a reaction of the general type:

$$
M O_{x(\text { condensed })}+\frac{y-x}{2} O_{2}=M O_{y \text { (gas) }} .
$$

The vapor pressure of the gaseous species is calculated from the equilibrium constant and the oxygen pressure:

$$
P_{M O_{y}}=K\left(P_{O_{2}}\right)^{\frac{y-x}{2}} .
$$

For elements having several gaseous oxides, $M_{x_{i}} O_{y_{i}}$, we calculated the equivalent pressure of the element in the gas phase as follows:

$$
P_{e}=\sum_{i} x_{i} P_{x_{i}} O_{y_{i}}
$$

assuming that the element was present as a monatomic gas. From this pressure, we derived the total vapor concentration by the ideal-gas law:

$$
\frac{n}{V}=\frac{P_{e}}{R T}\left(\frac{g \text {-atoms }}{\text { unit volume }}\right),
$$

where $\mathrm{n}$ is the number of $\mathrm{g}$-atoms of the fission product element.

\section{FISSION PRODUCT VOLATILITIES}

By use of the formulas in Sect. 3, the equilibrium vapor concentrations of Cs, Ru, Te, Tc, and Se were calculated at 300,500 , and $1000^{\circ} \mathrm{K}$ at oxygen pressures of $10^{-2}$ atm and $1 \mathrm{~atm}$ (Table 1).

The equilibrium data and the data for the stability of the condensed compounds at $500^{\circ} \mathrm{K}$ and higher were taken from the compilation of Bedford and Jackson, ${ }^{2}$ while the data at $300^{\circ} \mathrm{K}$ were taken either from Kubaschewski ${ }^{3}$ or were estimated. 
Table 1. Equilibrium Concentrations of Volatile Fission Products in Oxygen

\begin{tabular}{|c|c|c|c|c|c|c|}
\hline \multirow[b]{3}{*}{ Element } & \multicolumn{5}{|c|}{ Concentration of Element in Gas (mg/liter) when } & \\
\hline & \multicolumn{3}{|c|}{$\mathrm{P}_{\mathrm{O}_{2}}=1 \mathrm{~atm}$} & \multicolumn{3}{|c|}{$\mathrm{P}_{\mathrm{O}_{2}}=10^{-2} \mathrm{~atm}$} \\
\hline & $300^{\circ} \mathrm{K}$ & $500^{\circ} \mathrm{K}$ & $1000^{\circ} \mathrm{K}$ & $300^{\circ} \mathrm{K}$ & $500^{\circ} \mathrm{K}$ & $1000^{\circ} \mathrm{K}$ \\
\hline Cs & $1.00 \times 10^{-22}$ & $1.35 \times 10^{-15}$ & 3.55 & $1.33 \times 10^{-22}$ & $1.35 \times 10^{-14}$ & 1.12 \\
\hline Ru & $2.06 \times 10^{-14}$ & $1.47 \times 10^{-7}$ & $1.49 \times 10^{-2}$ & $2.06 \times 10^{-16}$ & $1.47 \times 10^{-9}$ & $1.49 \times 10^{-4}$ \\
\hline $\mathrm{Te}$ & $2.08 \times 10^{-31}$ & $3.41 \times 10^{-14}$ & $2.50 \times 10^{-1}$ & $2.08 \times 10^{-31}$ & $3.41 \times 10^{-14}$ & $2.50 \times 10^{-1}$ \\
\hline Tc & $1.71 \times 10^{-6}$ & $1.59 \times 10^{3}$ & $1.70 \times 10^{4}$ & $1.71 \times 10^{-6}$ & $1.60 \times 10^{3}$ & $5.36 \times 10^{4}$ \\
\hline $\mathrm{Se}$ & $1.05 \times 10^{-6}$ & $7.7 \times 10^{1}$ & a & $1.05 \times 10^{-6}$ & $7.7 \times 10^{1}$ & a \\
\hline
\end{tabular}

${ }^{a}$ No stable condensed compound. 


\section{FISSION PRODUCT YIELD}

The reference fuel for the fission product yields was a graphite fuel in which the $\mathrm{C} / \mathrm{Th}$ ratio was 200 and the $\mathrm{C} / \mathrm{U}$ ratio was 2750 . The initial ${ }^{235} \mathrm{U} /{ }^{232} \mathrm{Th}$ ratio was $6.8 \times 10^{-2}$. The calculation was made for a 2100 -day irradiation and a burnup of $84,000 \mathrm{Mwd} /$ metric ton. Table 2 shows the fission product concentrations in the fuel after 250 days cooling time. 5

Table 2. Fission Product Content of Reference Fuel After 250 Days of Cooling

\begin{tabular}{lc}
\hline Element & Grams of fission product \\
\hline${ }^{85} \mathrm{Kr}$ & $5.83 \times 10^{-6}$ \\
${ }^{103} \mathrm{Ru}$ & $2.68 \times 10^{-8}$ \\
${ }^{106} \mathrm{Ru}$ & $1.79 \times 10^{-6}$ \\
${ }^{127} \mathrm{Te}$ & $2.34 \times 10^{-8}$ \\
${ }^{129} \mathrm{Te}$ & $1.78 \times 10^{-3}$ \\
${ }^{137} \mathrm{Cs}$ & $3.27 \times 10^{-4}$ \\
$79 \mathrm{Se}$ & $3.15 \times 10^{-6}$ \\
99 & $2.08 \times 10^{-4}$ \\
\hline
\end{tabular}

\section{OFF-GAS ACTIVITY}

Combustion of the reference fuel (Table 2) in pure oxygen to give an assumed off-gas composition of $90 \% \mathrm{CO}_{2}, 5 \% \mathrm{CO}$, and a remainder of oxygen and volatile fission product oxides would yield 1.956 liters (at $300^{\circ} \mathrm{K}$ ) of off-gas per gram of burned fuel. Figure 1 shows the amounts of volatile fission products that can be present in this off-gas in equilibrium with $1 \mathrm{~atm}$ of oxygen. The data from Table 1 


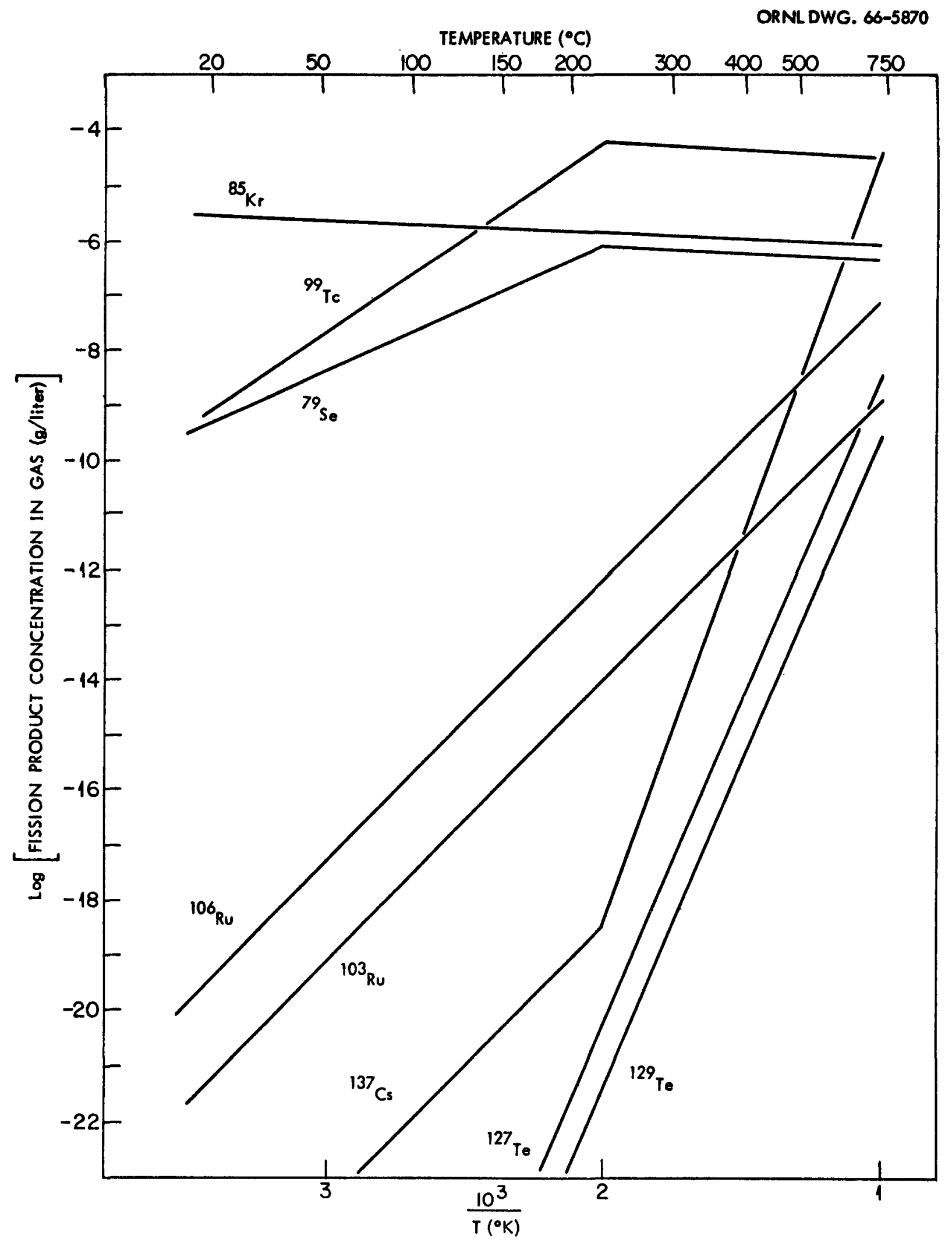

Fig. 1. Equilibrium Fission Product Concentration in Burner Off-Gas When Oxygen Pressure is 1 atm. 
for $10^{-2} \mathrm{~atm}$ of oxygen are not shown in Fig. I because reduction of the oxygen pressure to $10^{-2}$ atm would cause no important change. Figure 2 shows the activity of the off-gas in curies of fission product per liter of off-gas when the oxygen pressure is $1 \mathrm{~atm}$. At room temperature, the off-gas activity is dominated by the ${ }^{85} \mathrm{Kr}$ activity, but the technetium activity is also higher than the maximum permissible concentration in air. ${ }^{6}$ Table 3 shows the off-gas activity in curies/liter at $300^{\circ} \mathrm{K}$.

Table 3. Equilibrium Fission Product Activities in Burner Off-Gas at $300^{\circ} \mathrm{K}$ When Oxygen Pressure is $1 \mathrm{~atm}$.

\begin{tabular}{ll}
\hline Isotope & Curies/liter \\
\hline${ }^{85} \mathrm{Kr}$ & $1.23 \times 10^{-3}$ \\
$103 \mathrm{Ru}$ & $4.63 \times 10^{-17}$ \\
${ }^{106} \mathrm{Ru}$ & $4.42 \times 10^{-16}$ \\
${ }^{127} \mathrm{Te}$ & $4.08 \times 10^{-34}$ \\
${ }^{129} \mathrm{Te}$ & $8.26 \times 10^{-35}$ \\
${ }^{137} \mathrm{Cs}$ & $3.57 \times 10^{-24}$ \\
$79 \mathrm{Se}$ & $9.01 \times 10^{-11}$ \\
${ }^{99} \mathrm{Tc}$ & $3.06 \times 10^{-11}$ \\
\hline
\end{tabular}

\section{STACK DILUTION}

The above calculations indicate that cooling the burner off-gas to room temperature should result in condensation of very nearly all the volatile oxides. If the bulk of these oxides can be removed by efficient filters, the predominant remaining radionuclide would be ${ }^{85} \mathrm{Kr}$. Since its contribution to the off-gas would be $1.23 \mathrm{mc} /$ liter (Table 3), and since the maximum permissible concentration in air is, 


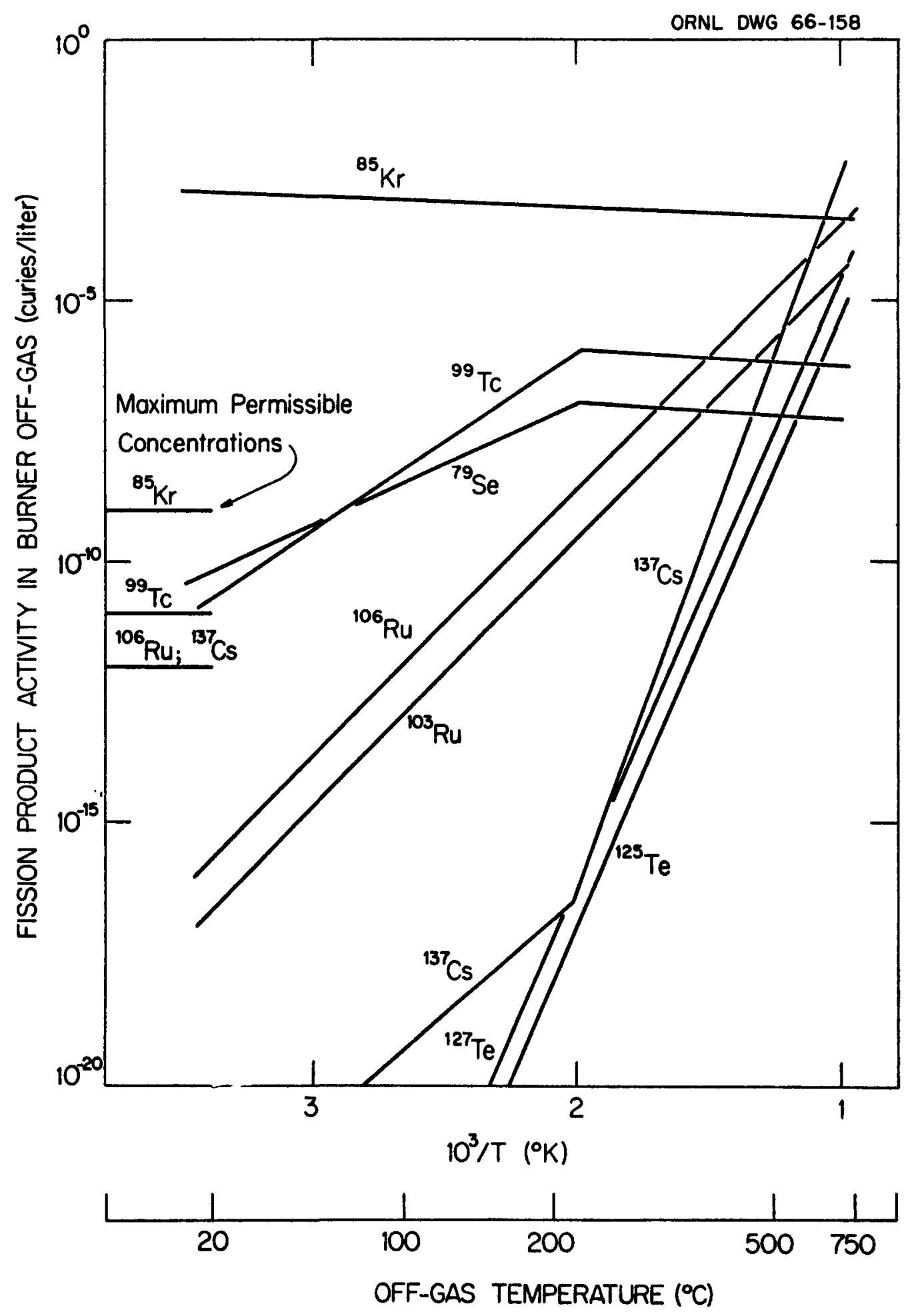

Fig. 2. Equilibrium Fission Product Activities in Burner Off-Gas When Oxygen Pressure Is 1 atm. 
according to Ref. $6,10^{-6} \mathrm{mc} /$ liter, a minimum dilution factor of about $10^{6}$ would be necessary before this off-gas could be released to the atmosphere. The reprocessing of the reference fuel specified above at a rate of $150 \mathrm{~kg}(T h+U)$ per day would result in an off-gas release of about 36 liters/sec. Since the ${ }^{85} \mathrm{Kr}$ activity is $1.23 \mathrm{mc}$ per liter, there would be a release of abo ut $44.2 \mathrm{mc} / \mathrm{sec}$, but release through a $100-m$ tall exhaust stack might be sufficient to provide the necessary millionfold dilution. For calculation of stack-to-ground dilution of this activity we used the data given by Nichols and Guthrie. ${ }^{7}$ They describe the concentration of an effluent, assuming no depletion by deposition or washout, by the Gaussian formula:

$$
x=\frac{Q}{\pi G_{i} G_{k} \bar{v}} \exp \left[-1 / 2\left(\frac{y^{2}}{G_{i}^{2}}+\frac{k^{2}}{G_{k}^{2}}\right)\right] \text {, }
$$

where

$X=$ concentration in curies per cubic meter,

$Q=$ source strength in curies per second,

$\bar{u}=$ mean wind speed in meters per second,

$y=$ cross wind distance in meters from the plume axis, which is assumed to coincide with the mean wind direction,

$k=$ source height in meters,

$G_{i}^{2}, G_{k}^{2}=$ dispersion coefficients in square meters.

Figure 3 shows the ${ }^{85} \mathrm{Kr}$ concentration in curies per cubic meter as a function of downwind distance, assuming the worst meteorological category of "extremely unstable conditions," a mean wind speed of $0.5 \mathrm{~m} / \mathrm{sec}$, and a $100-\mathrm{m}$ stack.

As seen from Fig. 3, the maximum krypton activity under the worst conditions is only slightly above the maximum permissible concentration. So, there is a possibility that the burner off-gas can actually be released into the atmosphere by a 100-m high stack. 
ORNL DWG. 66-5871

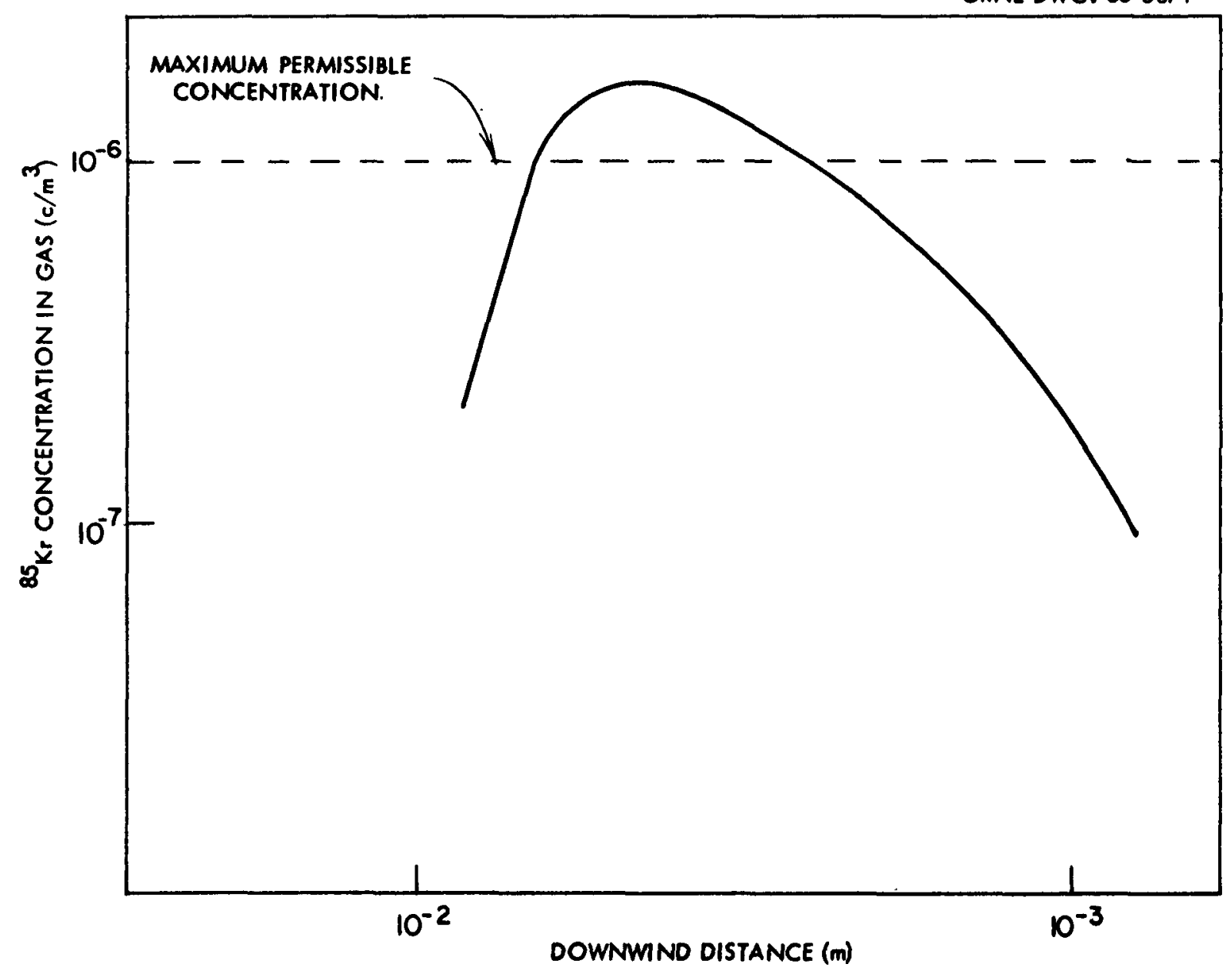

Fig. 3. ${ }^{85} \mathrm{Kr}$ Concentration in Plume-Diluted Gas As a Function of Downwind Distance. 


\section{CONCLUSION}

Calculations of fission product oxide $-\mathrm{O}_{2}$ equilibria showed, that at elevated temperature an appreciable amount of fission products will be present as volatile oxides in the off-gas from the combustion of graphite fuel. Cooling the offgas to room temperature is accompanied by condensation of practically all of the oxides. If the condensed oxides can be trapped by efficient filters, the remaining off-gas activity is limited by its ${ }^{85} \mathrm{Kr}$ content. This off-gas can possibly be released by a 100-m stack without further dilution.

\section{ACKNOWLEDGMENT}

The author thanks L. M. Ferris and E. L. Nicholson for many helpful discussions, and E. D. Arnold for calculation of the fission product yields.

\section{REFERENCES}

1. E. L. Nicholson, L. M. Ferris, and J. T. Roberts, Burn-Leach Processes for Graphite-Base Reactor Fuels Containing Carbon-Coated Carbide or Oxide Particles, ORNL-TM-1096 (April 1965).

2. R. G. Bedford and D. D. Jackson, Volatilities of the Fission Product and Uranium Oxides, UCRL-12314 (January 1965).

3. O. Kubaschewski and E. L. Evans, "Metallurgical Thermochemistry," Third Edition, Pergamon Press, London, 1958.

4. E. D. Arnold, Oak Ridge National Laboratory, unpublished data.

5. J. O. Blomeke and M. F. Todd, Uranium-235 Fission-Product Production as a Function of Thermal Neutron Flux, Irradiation Time, and Decay Time. . Atomic Concentrations and Gross Totals, ORNL-2 107, Part 1, Volumes 1 and 2 (Aug. 19, 1957).

6. "Maximum Permissible Body Burdens and Maximum Permissible Concentrations of Radionuclides in Air and in Water for Occupational Exposure," National Bureau of Standards Handbook 69, U. S. Department of Commerce, June 1959. 
7. C. E. Guthrie and J. P. Nichols, Theoretical Possibilities and Consequences of Major Accidents in U-233 and Pu-239 Fuel Fabrication and Radioisotope Processing Plants, ORNL-344.7 (April 1964). 


\section{INTERNAL DISTRIBUTION}

1. E. D. Arnold

2. R. E. Blanco

3. K. B. Brown

4. G. 1. Cathers

5. W. E. Clark

6. F. L. Culler

7. W. Davis, Jr.

8. D. E. Ferguson

9. L. M. Ferris

10. J. R. Flanary

11. H. E. Goeller

12. A. T. Gresky

13. B. A. Hannaford

14. W. O. Harms

15. J. A. Lane

16. E. L. Nicholson

17. R. H. Rainey

18. J. T. Roberts

19. D. B. Trauger

20. J. W. Ullman

21. C. D. Watson

22. Mo E. Whatley

23. R. G. Wymer

24 -33. H. O. Witte

34 - 35. Central Research Library

36. Document Reference Section

37 - 39. Laboratory Records Department

40. Laboratory Records, ORNL R.C.

41. ORNL Patent Office

42 - 56. Division of Technical Information Extension

57. Research and Development Division, ORO

\section{EXTERNAL DISTRIBUTION}

58. R. A. Pahler, USAEC, Washington

59. H. Schneider, USAEC, Washington

60. J. Nehls, USAEC, ORO 